\title{
EFFECT OF FOUR ANTIBIOTICS ON HAEMOLYSIN PRODUCTION AND ADHERENCE TO HUMAN UROEPITHELIAL CELLS BY ESCHERICHIA COLI
}

\author{
A. M. Shibl and C. G. Gemmell* \\ Microbiology Division, College of Pharmacy, University of Riyadh, Riyadh, Saudi \\ Arabia and *Department of Bacteriology, University of Glasgow, Royal Infirmary, \\ Glasgow
}

\begin{abstract}
Summary. The effect of subinhibitory concentrations of chloramphenicol, gentamicin, netilmicin and streptomycin in artificial culture media on growth, haemolysin production and adherence to uroepithelial cells by Escherichia coli was examined. Only streptomycin inhibited haemolysin production without inhibiting growth of the bacteria. In contrast, the inhibition of haemolysin production by chloramphenicol, gentamicin or netilmicin was directly proportional to the degree of inhibition of growth. Bacterial adherence to human uroepithelial cells, measured microscopically, was affected by all four antibiotics but to different extents. There was no correlation between inhibition of haemolysin biosynthesis and the ability of the bacteria to adhere to uroepithelial cells after growth in the presence of the antibiotics.
\end{abstract}

\section{INTRODUCTION}

Escherichia coli is the most common cause of urinary tract infections (UTI). Dudgeon, Wordley and Bawtree (1921) found a high incidence of haemolytic $E$. coli in patients with UTI. E. coli strains isolated from patients with UTI are usually of a serotype present in the faecal flora of the patient (Kunin, 1979) but often possess properties that distinguish them from the predominant faecal strains. In this context, their ability to adhere to mammalian cells may be important. E. coli strains isolated from patients with upper UTI have been shown to adhere more frequently to human uroepithelial cells than those isolated from patients with asymptomatic lower-tract infections or from normal faeces (Svanborg-Edén et al., 1976). This adherence is not inhibited by mannose and mannose-resistant adherence of $E$. coli to periurethral cells is closely associated with virulence and with haemagglutination of human erythrocytes (Fowler and Stamey, 1977). There is evidence that haemolysin is also linked to virulence (Minshew et al., 1978a, b).

Earlier results by Smith (1963) demonstrated that some strains of $E$. coli produced an extracellular haemolysin (designated $\alpha$-haemolysin) and a cell-associated

Received 7 Oct. 1982; accepted 26 Jan. 1983.

*Requests for reprints should be addressed to Dr C. G. Gemmell. 
haemolysin (designated $\beta$-haemolysin). Rennie and Arbuthnott (1974) suggested that $\alpha$-haemolysin may be an extracellular form of $\beta$-haemolysin, through complex formation by unidentified large-mol. wt factors in the medium with the cell-associated $\beta$-haemolysin. The finding that different strains produced different amounts of $\alpha$-haemolysin in nutrient broth (Snyder and Zwadyk, 1969) may reflect differences in the binding properties of the haemolysin to components of the bacterial cell surface. Springer and Goebel (1980) studied the synthesis of $E$. coli haemolysin in mineral-saltglucose medium and suggested that two transport processes are involved in haemolysin secretion. Haemolysin synthesised de novo is excreted through the cytoplasmic membrane by an energy-dependent process and accumulates temporarily in the periplasmic space. It is finally released through the outer membrane into the medium by an energy-independent but temperature-dependent step. Part of the present study was undertaken to determine the effect of various concentrations of four antibiotics upon growth and haemolysin production by $E$. coli, based upon earlier experiments with Staphylococcus aureus (Gemmell and Shibl, 1976), Streptococcus pyogenes (Gemmell and Amir, 1979) and Pseudomonas aeruginosa (Shibl and Al-Sowaygh, 1980).

Bacterial adhesion to epithelial surfaces is an important step in the establishment of infections involving mucosal surfaces. Fowler and Stamey (1977) showed that E. coli adhered better in vitro to vaginal epithelial cells from women prone to UTI than to cells from healthy controls. The ability of uropathogenic $E$. coli to adhere to the mucous surfaces of the urinary tract may be associated with virulence (Svanborg-Edén, Eriksson and Hanson, 1977; Svanborg-Edén et al., 1978). The ability of E. coli exposed to antibiotics to adhere to human uroepithelial cells was examined in the second part of this study. Subinhibitory concentrations of certain antibiotics can affect bacterial adherence (Ofek et al., 1979; Sandberg, Stenqvist and Svanborg-Edén, 1979; Vosbeck et al., 1979). However, we considered that the simultaneous examination of the expression of soluble and structural virulence factors in the presence of antibiotics was important to gain an understanding of the interaction of antibiotics with urinary-tract pathogens.

\section{MATERIALS AND METHODS}

Strain of E. coli. E. coli strain 127 isolated from a patient with UTI in the King Abdul-Aziz University Hospital, Riyadh, Saudi Arabia was used in this investigation because it produced haemolysin freely in culture. It was sensitive to the antibiotics employed in this study.

Growth and haemolysin production. The kinetics of growth and haemolysin production were followed during a 24-h period in cultures in $250 \mathrm{ml}$ of Brain-Heart Infusion Broth (BHI, Difco) in 1-L baffled flasks placed on an orbital shaker (Gallenkamp Ltd, Stockton-on-Tees) with a shaking speed of $150 \mathrm{rpm}$. Each flask was seeded with an 18 -h culture grown at $37^{\circ} \mathrm{C}$ to give an inoculum of $c .10^{7}$ viable cells $/ \mathrm{ml}$ of culture medium. The antibiotic solutions were added aseptically to the culture vessels. Samples were taken at various intervals thereafter for measurement of turbidity, viable count, $p \mathrm{H}$, and haemolytic activity.

The absorbance at $490 \mathrm{~nm}$ of the samples was measured by an SP200 spectrophotometer (Pye-Unicam, Cambridge) in cuvettes with a light path of $10 \mathrm{~mm}$. Viable counts were performed by the technique of Miles, Misra and Irwin (1938). The viable count was expressed as the number of colony forming units (cfu)/ml. The sample of the culture was clarified by centrifugation at $10000 \mathrm{~g}$ for $10 \mathrm{~min}$ in a High Speed 18 Centrifuge (Measuring and Scientific Equipment, Crawley) and the $p H$ of the supernate was measured. For the determination of haemolytic activity, fresh sheep red blood cells were washed three times in saline and veronal 
acetate buffer, $p \mathrm{H} 7 \cdot 3$, containing $10 \mathrm{mM} \mathrm{CaCl}_{2}$. Serial doubling dilutions of the supernate were made in $0.5 \mathrm{ml}$ of diluent (saline $75 \% \mathrm{v} / \mathrm{v}$, nutrient broth $25 \% \mathrm{v} / \mathrm{v}$ and merthiolate 1 in $10000,1 \%$ ) and $0.5 \mathrm{ml}$ of erythrocyte suspension $2 \%(\mathrm{v} / \mathrm{v})$ was added to each tube. The tubes were incubated for $60 \mathrm{~min}$ in a thermostatically-controlled water bath at $37^{\circ} \mathrm{C}$ with shaking and the $50 \%$ haemolysis end-point was assayed visually. The highest dilution that caused $50 \%$ haemolysis in these conditions was considered to contain one minimum haemolytic unit $/ \mathrm{ml}$ $(1 \mathrm{HU} / \mathrm{ml})$.

Protein content was estimated by the method of Lowry et al. (1951) with bovine serum albumin (Armour Pharmaceutical Ltd, Eastbourne) as the standard.

Antibiotics used were streptomycin sulphate (Eli Lilly, Indianapolis) gentamicin and netilmicin (Schering Corp., Detroit) and chloramphenicol (Parke-Davis, Detroit). Fresh aqueous solutions of each antibiotic were prepared before each experiment. The minimal inhibitory concentration (MIC) of each antibiotic for $E$. coli 127 was determined as follows: serial doubling dilutions of antibiotic were made in BHI broth and the tubes were seeded with $E$. coli $10^{5} \mathrm{cfu} / \mathrm{ml}$. The MIC was the lowest concentration of antibiotic that prevented obvious turbidity after incubation for $18 \mathrm{~h}$ at $37^{\circ} \mathrm{C}$.

Adherence of bacteria to human uroepithelial cells was studied by the method of Svanborg-Edén et al. (1977). Samples $(50 \mathrm{ml})$ of urine were obtained each morning from healthy young women and centrifuged at $350 \mathrm{rpm}$ for $10 \mathrm{~min}$ to harvest uroepithelial cells. The numbers of cells were estimated by microscopy with a counting chamber. E. coli 127 was harvested from 16-h broth cultures (BHI) grown without antibiotic or with a subinhibitory concentration of each antibiotic separately. The bacteria were re-suspended in phosphate-buffered saline $(p \mathrm{H} 7 \cdot 2)$ and counted.

To measure adherence, $10^{8}$ bacteria were allowed to interact with $10^{5}$ uroepithelial cells in a total volume of $1 \mathrm{ml}$ for $60 \mathrm{~min}$ at $37^{\circ} \mathrm{C}$ with shaking. Any unattached bacteria were removed by gentle centrifugation $(150 \mathrm{~g})$ and the cells re-suspended in $1 \mathrm{ml}$ of $0.04 \mathrm{M}$ phosphate buffered saline $(p H$ 7.2) and washed twice. Thereafter, one drop of the mixture was placed on a microscope slide and covered with a glass cover slip. Cell suspensions without added bacteria were included as negative controls. When more than 20 bacteria were present on an individual cell, the count was recorded as $>20$, because greater numbers of bacteria/cell could not be counted accurately. The number of bacteria on 40 uroepithelial cells was counted in each experiment.

Localisation of haemolysin in E. coli strain 127. Samples of bacteria were harvested by centrifugation and washed with 20 -ml volumes of $0.05 \mathrm{M}$ tris-sodium chloride buffer, $p \mathrm{H} \mathrm{7.4}$ until the washing fluid was free from detectable haemolytic activity. The packed cells were resuspended in the same buffer so that the suspension contained $1 \mathrm{mg}$ (dry weight) of cells $/ \mathrm{ml}$. Cells were disrupted by ultrasonication (Measuring and Scientific Equipment, Crawley) in an ice-bath for a total of $3 \mathrm{~min}$ in 30-s pulses, each followed by a cooling period in ice to hold the temperature at $2-4^{\circ} \mathrm{C}$. After sonication, the supernate and cell debris were separated by centrifugation at $10000 \mathrm{~g}$ and assayed for haemolytic activity.

\section{RESULTS}

\section{Production of haemolysin by E. coli strain 127}

Preliminary experiments showed that BHI allowed production of high titres of haemolysin consistently. Haemolytic activity was first detectable early in the growth cycle and increased proportionately during the logarithmic phase. As the culture entered the stationary phase of growth, haemolysin production reached $512 \mathrm{HU} / \mathrm{ml}$. Ultrasonic disruption of the cells at various times revealed that the haemolysin was wholly extracellular and did not accumulate intracellularly before release from the cell. 


\section{Effect of antibiotics on haemolysin production}

A subinhibitory concentration of streptomycin $(1.5 \mu \mathrm{g} / \mathrm{ml})$ equal to half of the MIC caused a $29 \%$ reduction in growth rate compared with an antibiotic-free control culture during the early stages of incubation (fig. 1). However, this concentration caused complete inhibition of haemolysin production. Three other antibiotics that have a similar mode of action to streptomycin (i.e., they inhibit protein biosynthesis), were then compared for their effect on haemolysin production. Subinhibitory concentrations of chloramphenicol $(1.5 \mu \mathrm{g} / \mathrm{ml})$, gentamicin $(0.7 \mu \mathrm{g} / \mathrm{ml})$ or netilmicin $(0.7 \mu \mathrm{g} / \mathrm{ml})$ had no effect on haemolysin production without a corresponding inhibition of growth (table I).

Addition of streptomycin $1.5 \mu \mathrm{g} / \mathrm{ml}$ at various times during the cultivation of $E$. coli

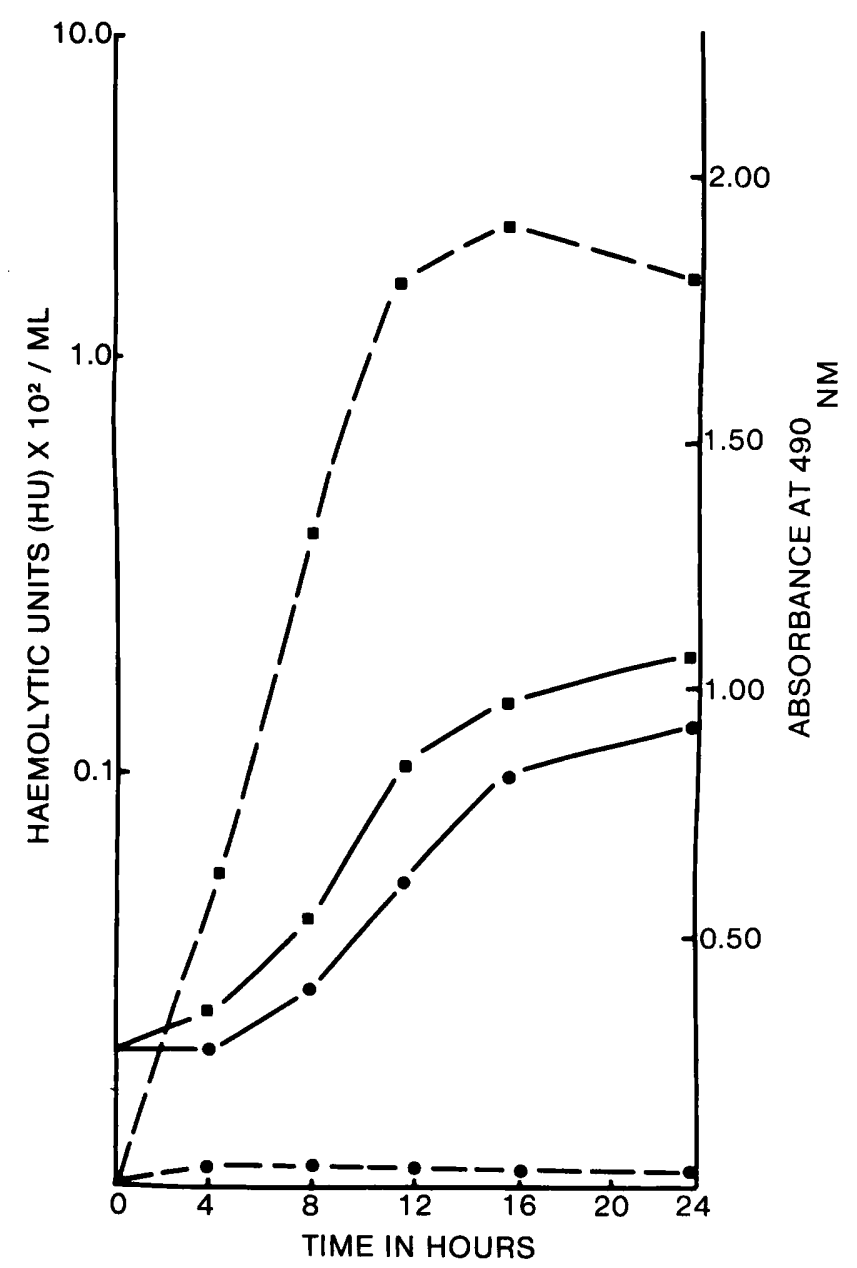

FIG. 1.-Effect of streptomycin $1.5 \mu \mathrm{g} / \mathrm{ml}$ on growth and haemolysin production by $E$. coli strain 127 ; growth in absence of streptomycin, growth in presence of streptomycin, haemolysin produced in absence of streptomycin, streptomycin. 
TABLE I

Effect of antibiotics on growth and haemolysin production by E. coli

\begin{tabular}{|c|c|c|c|c|c|c|c|c|}
\hline \multirow[b]{3}{*}{$\begin{array}{c}\text { Time of } \\
\text { Sampling } \\
\text { (h) }\end{array}$} & \multicolumn{8}{|c|}{ Density of growth and haemolytic activity in cultures with } \\
\hline & \multicolumn{2}{|c|}{ No antibiotic } & \multicolumn{2}{|c|}{ Chloramphenicol* } & \multicolumn{2}{|c|}{ Gentamicin* } & \multicolumn{2}{|c|}{ Netilmicin* } \\
\hline & Growth $\uparrow$ & $\begin{array}{c}\text { Haemolytic } \\
\text { activity } \\
(\mathrm{HU} / \mathrm{ml})\end{array}$ & Growth $\dagger$ & $\begin{array}{c}\text { Haemolytic } \\
\text { activity } \\
\text { (HU/ml) }\end{array}$ & Growth $\uparrow$ & $\begin{array}{c}\text { Haemolytic } \\
\text { activity } \\
(\mathrm{HU} / \mathrm{ml})\end{array}$ & Growth $\dagger$ & $\begin{array}{c}\text { Haemolytic } \\
\text { activity } \\
(\mathrm{HU} / \mathrm{ml})\end{array}$ \\
\hline $\begin{array}{r}4 \\
8 \\
12 \\
16 \\
24\end{array}$ & $\begin{array}{r}40 \\
87 \\
160 \\
210 \\
275\end{array}$ & $\begin{array}{r}8 \\
64 \\
256 \\
512 \\
256\end{array}$ & $\begin{array}{r}32 \\
57 \\
120 \\
160 \\
214\end{array}$ & $\begin{array}{r}4 \\
32 \\
216 \\
512 \\
256\end{array}$ & $\begin{array}{r}29 \\
44 \\
98 \\
121 \\
167\end{array}$ & $\begin{array}{r}4 \\
4 \\
16 \\
128 \\
256\end{array}$ & $\begin{array}{r}30 \\
61 \\
121 \\
170 \\
201\end{array}$ & $\begin{array}{r}4 \\
32 \\
129 \\
256 \\
512\end{array}$ \\
\hline
\end{tabular}

* The concentration of each drug was half of the MIC for E. coli strain 127 (chloramphenicol $1.5 \mu \mathrm{g} / \mathrm{ml}$; gentamicin and netilmicin $0.7 \mu \mathrm{g} / \mathrm{ml}$ ).

$\dagger$ Growth measured as absorbance at $490 \mathrm{~nm}$ (see Methods).

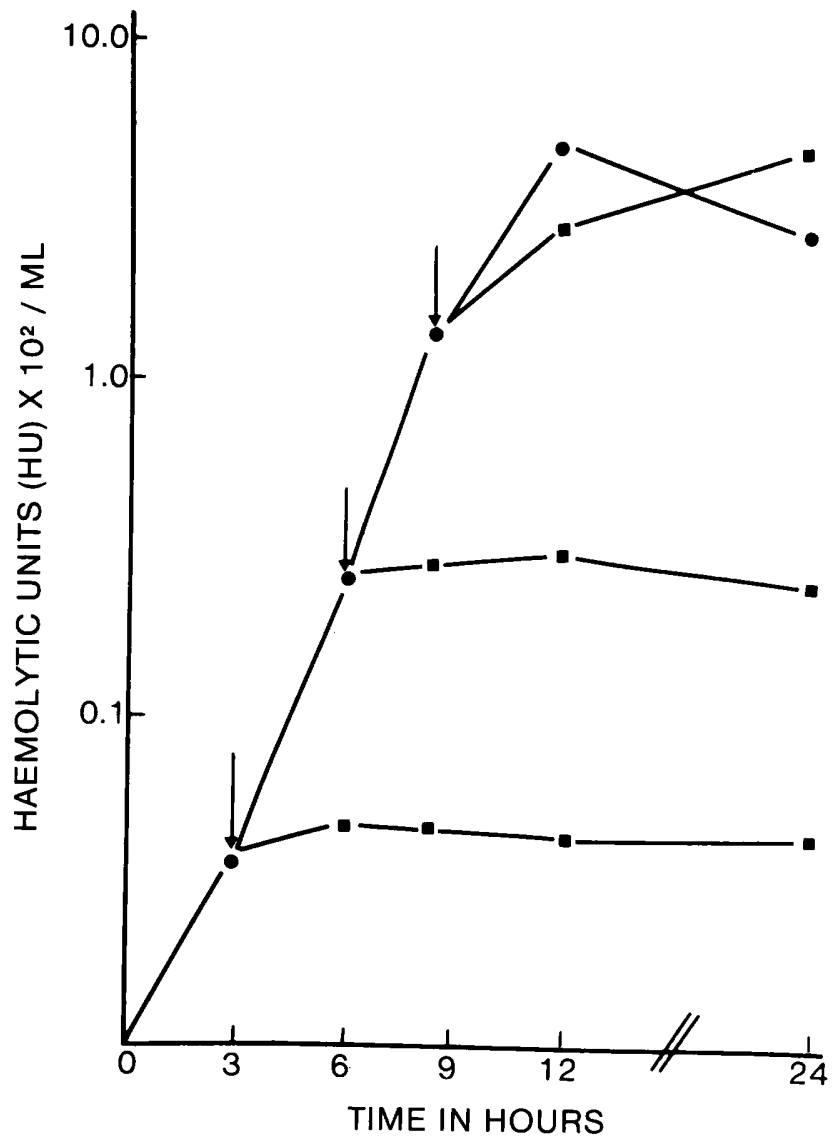

FIG. 2.-Effect of streptomycin $1.5 \mu \mathrm{g} / \mathrm{ml}$ added at various times (arrows) in the growth cycle on haemolysin production by $E$. coli strain 127 ; 
showed that the drug caused complete repression of further haemolysin biosynthesis for up to $6 \mathrm{~h}$ when added in the mid-logarithmic phase of the culture (fig. 2).

\section{Effect of streptomycin on haemolysin and protein biosynthesis by E. coli strain 127}

The amounts of extracellular protein produced throughout the growth cycle by the cultures of $E$. coli strain 127 grown in the presence or absence of streptomycin were compared. Estimates of exoprotein were based upon the dry weight of bacterial cells in each culture. The yields of exoprotein and haemolysin after $16 \mathrm{~h}$ are summarised in table II. As well as revealing a complete inhibition of haemolysin production, these show that the amount of exoprotein produced by the $E$. coli cells was reduced by $50 \%$ in the presence of streptomycin compared with production in antibiotic-free medium. Streptomycin had no inactivating effect on haemolysin activity at the concentration used.

\section{Effect of antibiotics on adhesion of E. coli strain 127 to uroepithelial cells}

The influence of subinhibitory concentrations of each antibiotic on adhesion is shown in table III. When E. coli strain 127 was grown in the presence of an antibiotic

\section{TABLE II}

The effect of streptomycin on extracellular protein and haemolysin biosynthesis by E. coli strain 127

\begin{tabular}{lcc}
\hline \multicolumn{1}{c}{ Conditions of growth } & $\begin{array}{c}\text { Extracellular } \\
\text { protein }\end{array}$ & $\begin{array}{c}\text { Haemolytic activity } \\
(\mathrm{HU} / \mathrm{ml})\end{array}$ \\
\hline Antibiotic-free medium & 18 & 512 \\
Medium plus streptomycin $1.5 \mu \mathrm{g} / \mathrm{ml} \dagger$ & 9 & 4 \\
\hline
\end{tabular}

* Protein synthesis expressed as $\mu \mathrm{g} / \mathrm{mg}$ dry weight of cells.

$\dagger$ MIC of streptomycin for strain $127=3 \mu \mathrm{g} / \mathrm{ml}$.

\section{TABLE III}

Effect of growing E. coli in the presence of subinhibitory concentration of four antibiotics on their ability to adhere to human uroepithelial cells in vitro

\begin{tabular}{lcc}
\hline \multicolumn{1}{c}{$\begin{array}{c}\text { Antibiotic added to } \\
\text { growth medium }\end{array}$} & $\begin{array}{c}\text { Mean numbers of adherent } \\
\text { bacteria/cell (range) }\end{array}$ & $\begin{array}{c}\text { Percentage } \\
\text { adhesion } \\
\text { (control=100\%) }\end{array}$ \\
\hline $\begin{array}{l}\text { None (control)* } \\
\text { Chloramphenicol } 1.5 \mu \mathrm{g} / \mathrm{ml} \dagger\end{array}$ & $\begin{array}{c}7.3 \\
(6-10)\end{array}$ & $\begin{array}{c}100 \\
\text { (11.3 }\end{array}$ \\
Gentamicin $0.7 \mu \mathrm{g} / \mathrm{ml} \dagger$ & $(10-12)$ & 56.3 \\
Netilmicin $0.7 \mu \mathrm{g} / \mathrm{ml} \dagger$ & 13.8 & 68.8 \\
Streptomycin $1.5 \mu \mathrm{g} / \mathrm{ml} \dagger$ & $(13-14)$ & 27.5 \\
& $(5-6)$ & \\
\hline
\end{tabular}

* The difference between the control and any treatment by antibiotic was significant according to Turkey's test.

$\dagger$ The difference between treatments was significant $(p<0.001)$. 
the adhesive ability of the cells was affected to different extents with different antibiotics. Streptomycin and chloramphenicol caused the greatest suppression of adherence; the numbers of bacteria adhering to the surface of the uroepithelial cells were reduced to $27.5 \%$ and $36.3 \%$ respectively when compared with those bacteria grown in the absence of antibiotics.

\section{Discussion}

Although little is known of the cultural conditions required for haemolysin synthesis, relatively simple media allow production of adequate quantities. The present results suggest that haemolysin is produced early in the growth cycle, reaching a maximum concentration after 8-12 $\mathrm{h}$-before any cell autolysis occurs. Cellular disruption by sonication showed that the haemolysin does not accumulate intracellularly before release into the culture medium, thus satisfying the minimal criteria for an extracellular product outlined by Raynaud and Alouf (1970).

Streptomycin binds to the 30 S sub-unit of the bacterial ribosome; it has no effect on mRNA or its binding by the ribosome (Hash, 1972). The outcome of an effect solely on the ribosome would be that no more haemolysin would be synthesised in the cell and any preformed pool in the cytoplasm would quickly be lost from the cell to the surrounding medium. When cells grown in the presence of streptomycin were disrupted ultrasonically no intracellular pool of haemolysin was detected, which indicates that the antibiotic affects haemolysin formation de novo and not its release from the cells. A similar mechanism to explain the effect of lincomycin on the formation of $\alpha$ - and $\delta$-haemolysins by $S$. aureus has been proposed (Gemmell and Shibl, 1976). The observation in the present study of a highly selective inhibition of haemolysin biosynthesis might be explained by the existence of two classes of ribosomes with different sensitivities to streptomycin: one located at the periphery of the cell, perhaps associated with the cytoplasmic membrane, and the other more-orless uniformly distributed in the cytoplasm.

Both et al. (1972) proposed that the site of extracellular enzyme synthesis is located on the inside of the membrane. Membrane-bound ribosomes occur in bacteria and account for at least $30 \%$ of the total polyribosomes in E. coli (Varricchio, 1972). Cancedda and Schlesinger (1974) have implicated these polysomes in the synthesis of alkaline phosphatase by $E$. coli. Preliminary results show that streptomycin inhibits alkaline phosphatase production (A. Shibl, unpublished observations) in the same conditions as haemolysin production was inhibited. The precise function of membrane-bound ribosomes remains unknown, although they may represent the site of synthesis of certain macromolecules, including exotoxins. Abbas-Ali and Coleman (1977) have shown that exoprotein synthesis in S. aureus, which occurs primarily in the early part of the logarithmic phase of growth, may account for only $33 \%$ of the total bacterial protein formed. This suggests that much of the biosynthetic potential of the cell is consumed by this process and, therefore, may be open to inhibition by antibiotics as seen in the present experiments.

The ability of $E$. coli to adhere to uroepithelial cells depends upon the presence of pili on the surface of the cells. The pili also participate in the haemagglutination of human erythrocytes (Minshew et al., 1978a, b) and repression of their synthesis by 
subinhibitory concentrations of certain antibiotics reduces the ability of $E$. coli to haemagglutinate erythrocytes and to adhere to buccal epithelial cells (Vosbeck, Bohn and Huber, 1980). Adhesion of $E$. coli was reduced significantly after growth in the presence of subinhibitory concentrations of aminoglycosides or tetracycline but not chloramphenicol. Their finding with chloramphenicol contrasts with ours; however, a different type of epithelial cell was used in each study. There was no correlation between repression of haemolysin biosynthesis and adherence with any of the four antibiotics tested in our study.

\section{REFERENCES}

AbBas-Ali, B. AND Coleman, G. 1977. The characteristics of extracellular protein secretion by Staphylococcus aureus (Wood 46) and their relationship to the regulation of $\alpha$-toxin formation. Journal of General Microbiology, 99, 277-282.

Both, G. W., McInNes, J. L., Hanlon, J. E., MaY, B. K. and Elliott, W. H. 1972. Evidence for an accumulation of messenger RNA specific for extracellular protease and its relevance to the mechanism of enzyme secretion in bacteria. Journal of Molecular Biology, 67, 199-217.

CANCEDda, R. AND Schlesinger, M. J. 1974. Localisation of polyribosomes containing alkaline phosphatase nascent polypeptides on membranes of Escherichia coli. Journal of Bacteriology, 117, 290-301.

DUdGEON, L. S., WORDLEY, E. AND BAWTREE, F. 1921. On Bacillus coli infections of the urinary tract especially in relation to haemolytic organisms. Journal of Hygiene, 20, 137-164.

FOWLER, J. E. AND STAMEY, T. A. 1977. Studies of introital colonization in women with recurrent urinary infections. VIII. The role of bacterial adherence. Journal of Urology, $117,472-476$.

Gemmell, C. G. AND AmIR, M. K. A. 1979. Effect of certain antibiotics on the formation of cellular antigens and extracellular products by group-A streptococci. In Pathogenic streptococci, edited by M. T. Parker, Reedbooks, Chertsey, pp. 67-68.

Gemmell, C. G. AND ShiBl, A. M. 1976. The control of toxin and enzyme biosynthesis in staphylococci by antibiotics. In Staphylococci and Staphylococcal Infections, edited by J. Jeljaszewicz, Fischer Verlag, Stuttgart. pp. 657-664.

Hash, J. H. 1972. Antibiotic mechanisms. Annual Reviews of Pharmacology, 12, 35-56.

Kunin, C. M. 1979. Detection, prevention and management of urinary tract infections, $3 \mathrm{ed.}$, Lea and Febiger, Philadelphia, pp. 123-126.

Lowry, O. H., Rosebrough, N. J., FarR, A. L. AND Randall, R. J. 1951. Protein measurement with the folin phenol reagent, Journal of Biological Chemistry, 193, 265-275.

Miles, A. A., MisRa, S. S. AND IRWIN, J. O. 1938. The estimation of the bactericidal power of the blood. Journal of Hygiene, 38, 732-749.

Minshew, B. H., Jorgensen, J., Counts, G. W. AND Falkow, S. 1978a. Association of hemolysin production, hemagglutination of human erythrocytes and virulence for chicken embryos of extraintestinal Escherichia coli isolates. Infection and Immunity, 20, 50-54.

Minshew, B. H., Jorgensen, J., Swanstrum, M., Grootes-Reuvecamp, G. A. and Falkow, S. 1978b. Some characteristics of Escherichia coli strains isolated from extraintestinal infections of humans. Journal of Infectious Diseases, 137, 648-654.

Ofek, I., Beachey, E. H., Eisenstein, B. I., Alkan, M. L. ANd Sharon, N. 1979. Suppression of bacterial adherence by subminimal inhibitory concentrations of $\beta$-lactam and aminoglycoside antibiotics. Reviews of Infectious Diseases, 1, 832-837.

Raynaud, M. AND Alouf, J. E. 1970. Intracellular versus extracellular toxins. In Microbial Toxins vol. 1, edited by S. J. Ajl, S. Kadis and T. C. Montie. Academic Press Inc., New York. pp. 67-117.

Rennie, R. P. AND Arbuthnotr, J. P. 1974. Partial characterisation of Escherichia coli haemolysin. Journal of Medical Microbiology, 7, 179-188.

SANDBERG, T., STENQVist, K. AND SVANBORG-EDÉN, C. 1979. Effect of subminimal inhibitory concentrations of ampicillin, chloramphenicol and nitrofurantoin on the attachment of 
Escherichia coli to human uroepithelial cells in vitro. Reviews of Infectious Diseases, 1, 836-844.

ShiBL, A. M. AND Al-SowAYGH, I. A. 1980. Antibiotic inhibition of protease production by Pseudomonas aeruginosa. Journal of Medical Microbiology, 13, 345-349.

SNYDER, I. S. AND ZWADYK, P. 1969. Some factors affecting production and assay of Escherichia coli haemolysins. Journal of General Microbiology, 55, 139-143.

SMITH, H. W. 1963. The haemolysins of Escherichia coli. Journal of Pathology and Bacteriology, 85, 197-211.

SPRINGER, W. AND GOEBEL, W. 1980. Synthesis and secretion of hemolysin by Escherichia coli. Journal of Bacteriology, 144, 53-59.

Svanborg-EdÉn, C., ERIKsson, B. AND Hanson, L. A. 1977. Adhesion of Escherichia coli to human uroepithelial cells in vitro. Infection and Immunity, 18, 767-774.

Svanborg-Edén, C., Eriksson, B., Hanson, L. A., Jodal, U., KaIJSER, B., Liden-Janson, G., LINDBERG, U. AND Olling, S. 1978. Adhesion to normal human uroepithelial cells of Escherichia coli from children with various forms of urinary tract infection. Journal of Pediatrics, 93, 398-403.

Svanborg-Edén, C., Hanson, L. A., Jodal, U., Lindberg, U. and Akerlund, A. S. 1976. Variable adherence to normal human urinary-tract epithelial cells of Escherichia coli strains associated with various forms of urinary-tract infection. Lancet, 2, 490-492.

VARRICCHIO, F. 1972. "Compartmentalization" of Escherichia coli ribosomes and ribonucleic acid. Journal of Bacteriology, 109, 1284-1294.

Vosbeck, K., Handschin, H., Menge, E. B. AND ZAK, O. 1979. Effects of subminimal inhibitory concentrations of antibiotics on adhesiveness of Escherichia coli in vitro. Reviews of Infectious Diseases, 1, 845-851.

VOSBECK, K., BOHN, J. AND HUBER, U. 1980. Adhesiveness, hemagglutination and piliation of Escherichia coli grown in sub-MIC concentrations of antibiotics. Experientia, 36, 494. 